\title{
Mutậ̂ầsith
}

JURNAL HUKUM ISLAM

\section{PENERAPAN FATWA DEWAN SYARIAH NASIONAL TENTANG HUKUM JAMINAN DALAM AKAD PEMBIAYAAN MUDHARABAH}

\author{
Rd. Nurhayati, Muhammad Saleh, Abdullah Sani Kurniadinata \\ Fakultas Syariah dan IImu Hukum, UIN Sunan Gunung Djati Bandung, Indonesia \\ STAIJM \\ Email: Hetty_noer65@yahoo.com
}

\begin{abstract}
Abstrak
Dalam kajian fikih klasik, akad mudharabah merupakan akad yang dilandaskan pada unsur kepercayaan (trust) sehingga dalam aplikasi pembiayaan mudharabah tidak diperlukan adanya agunan atau jaminan. Seiring dengan perkembangan zaman dan karakter manusia dalam menjalankan bisnis, terjadi pergesesaran pemikiran sehingga diperlukan ijtihad baru untuk suatu permasalahan salah satunya akad pembiayaan mudharabah. Tujuan penelitian ini untuk mengetahui ketentuan jaminan dalam penyaluran pembiayaan mudharabah di lembaga keuangan non bank, jaminan dalam fatwa DSN tentang pembiayaan mudharabah, serta penerapan fatwa DSN tentang jaminan dalam akad pembiayaan mudharabah. Penelitian ini menggunakan pendekatan deskriptif kualitatif, dilakukan dengan mengumpulkan data kemudian mendeskripsikan dari observasi wawancara dan dokumentasi. Dari hasil penelitian ini dapat disimpulkan bahwa penerapan fatwa Dewan Syariah Nasional (DSN) tentang jaminan dalam akad pembiayaan mudharabah ini yaitu berdasarkan sikap masyarakat dewasa ini yang sering melakukan penyimpangan sosial (moral hazard) terutama dalam pembiayaan mudharabah yang memang memiliki resiko yang sangat tinggi. Fungsi jaminan itu ialah tidak dimaksudkan untuk niat mendzolimi tetapi sebagai pengendalian terhadap kemungkinan terjadinya penyimpangan oleh mudharib, untuk itulah DSN mengeluarkan fatwa yang harus ditaati oleh Lembaga Keuangan Syariah salah satunya BMT Al-Amanah Ciawi Tasikmalaya berdasarkan fatwa DSN No: 07/DSN-MUI/IV/2000 tentang pembiayaan mudharbah.
\end{abstract}

Kata kunci : fatwa dewan syariah nasional, jaminan, mudharabah

\section{Abstract}

In classical figh study, akad Mudharabah is a contract that is based on the element of Trust (trust) so that in the application of financing mudharabah not necessary collateral or guarantees. Along with the development of the Times and the human character in running the business, there is a thought of thinking so that it is necessary to ijtihad new to a problem one of them Akad Mudharabah. The purpose of this research is to determine theprovisions of the guarantee in the distribution of Mudharabah financing in non-bank financial institutions, the guarantee in the fatwa DSN on Mudharabah financing, and the application of the fatwa DSN about the assurance in the Mudharabah financing contract This study uses a qualitative descriptive approach, conducted by collecting data and then describing the observation of interviews and documentation. From the results of this research can be concluded that the application of the fatwa of the National Sharia Board (DSN) about the guarantee in this Mudharabah financing is based on the attitude of society today that often do social irregularities (moral hazard), especially in Mudharabah financingthat does not have a very high risk. The function of the guarantee is not intended for mendzolimi intention but as a control of the 
Penerapan Fatwa Dewan Syariah Nasional Tentang Hukum Jaminan

Dalam Akad Pembiayaan Mudharabah

possibility of deviations by mudharib, therefore, the DSN issued a fatwa that must be obeyed by Sharia financial institutions one of the BMT

Al-Amanah Ciawi Tasikmalaya based on the fatwa DSN No: 07/DSN-MUI/IV/2000 on

Mudharbah financing.

Keywords: fatwa board of national sharia, guarantees, mudharabah

PENDAHULUAN

Berkembangnya perekonomian dewasa ini mengakibatkan banyaknya permintaan dan kebutuhan pendanaan yang dibutuhkan oleh masyarakat, entah itu untuk usaha, kredit kendaraan, rumah atau keperluan lainnya yang bersifat primer dengan cara yang mudah dan aman. Tujuan ekonomi Islam adalah untuk mewujudkan perekonomian jangka panjang dan memaksimalkan kesejahteraan manusia. ${ }^{1} \mathrm{Di}$ Indonesia ekonomi Islam memiliki fungsi sebagai pelengkap atau sebagai kontrol terhadap sistem ekonomi konvensianal, karena ekonomi yangberjalaan saat ini kurang bisa memunculkan keadilan dan belum efektif mengentaskan kemiskinan, oleh karena itu sudah selayaknya ekonomi Islam memberikan perubahan untuk umatnya sebagai alternatif atau solusi perkembangan ekonomi yang sudah berjalan saat ini.

Perkembangan ekonomi Islam di Indonesia dapat dibuktikan dengan kehadiran Lembaga Keuangan Mikro (LKM) yang dinilai memiliki peran penting untuk mendukung program pemerintah dalam mengentaskan kemiskinan. Lembaga Keuangan Mikro adalah lembaga yang memberikan jasa keuangan bagi pengusaha mikro dan masyarakat berpenghasilan rendah, baik formal, semi formaldan informal. Lembaga Keuangan Mikro memiliki produk yang relatif lengkap dan sesuai dengan kebutuhan masyarakat berpenghasilan rendah. Jenis lembaga keuagan mikro ada berbagai macam bentuk.

Salah satunya adalah Baitul Maal Wa Tamwil (BMT) yang merupakan lembaga keuangan mikro dengan prinsip syariah. Baitul Maal Wa Tamwil adalah lembaga keuangan dengan konsep syariah yang lahir sebagai pilihan yang menggabungkan konsep maal dan tamwil dalam satu kegiatan lembaga. Dimana Baitul Maal merupakan istilah untuk organisasi yang berperan dalam mengumpulkan dan menyalurkan dana non profit, seperti zakat, infak dan sedekah. Sedangkan, Baitul Tamwil merupakan istilah untuk organisasi yang mengumpulkan dan menyalurkan dana komersial melalui pinjaman pembiayaan. dengan demikian BMT mempunyai peran ganda yaitu fungsi sosial dan fungsi komersial ${ }^{2}$

Kehadiran lembaga keuangan mikro syariah yang bernama BMT dirasakan telah membawa manfaat fnancial bagi masyarakat, terutama masyarakat kecil yang

\footnotetext{
${ }^{1}$ Heri Sudarsono, Bank dan Lembaga Keuangan Syari'ah, (Yogyakarta: Ekonisia, 2004), hlm. 1.

2 Neni Sri Imaniyati, Aspek-aspek Hukum BMT, (Bandung: PT.Citra Aditya Bakti, 2010), hIm.71.
} 
Penerapan Fatwa Dewan Syariah Nasional Tentang Hukum Jaminan

Dalam Akad Pembiayaan Mudharabah

tidak bankable dan menolak riba. Kehadiran BMT di satu sisi menjalankan misi ekonomi syariah dan di sisi lain mengemban tugas ekonomi kerakyatan dengan meningkatkan ekonomi mikro, itulah sebabnya perkembangan BMT sangat pesat di tengah perkembangan lembaga keuangan mikro konvensional lainya. ${ }^{3}$

Dalam lembaga keuangan syariah telah diperkenalkan beberapa instrumen keuangan sebagai pengganti instrumen bunga. Instrumen tersebut adalah sebuah instrumen yang lebih mengedepankan prinsip bagi hasil (profit and loss sharing). Keuntungan yang diperoleh dan kerugian yang diderita ditanggung secara bersamasama oleh pihak yang melakukan transaksi. Oleh karena itu, kedua belah pihak yang melakukan transaksi akan saling memperhatikan kemajuan dan kemunduran usaha yang dijalankan. Diantara prisnip bagi hasil yang paling menonjol dan bahkan paling populer adalah mudharabah.

Secara sederhana mudharabah dapat diartikan sebagai akad kerja sama antara pemilik modal (shahibul maal) dan pengelola modal (mudharib) untuk melakukan usaha tertentu dengan pembagian keuntungan berdasarkan nisbah bagi hasil. Menurut Warkum Sumitro, pada produk pembiayaan mudharabah ini diperlukan adanya jaminan. Bentuk jaminan yang diterapkan dalam lembaga keuangan syariah sama dengan bentuk jaminan yang diterapkan pada lembaga keuangan konvensional, yaitu terdiri atas jaminan perorangan dan jaminan kebendaan. ${ }^{4}$ Jaminan merupakan salah satu hal penting bagi lembaga keuangan dalam rangka melaksanakan prinsip kehati-hatian (prudential pronciple). Prinsip kahatihatian adalah pengendalian risiko melalui penerapan peraturan perundangundangan dan ketentuan yang berlaku secara konsisten. ${ }^{5}$

BMT Al-Amanah Ciawi merupakan salah satu lembaga keuangan mikro yang dalam operasionalnya meliputi penghimpunan dana (funding), pembiayaan (financing). Dari sisi penghimpunan dana BMT AIAmanah Ciawi menghimpun dana melalui simpanan atau tabungan anggota, sedangkan dari sisi pembiayaan, BMT AlAmanah Ciawi dapat menyalurkan pembiayaan berdasarkan akad-akad yang sesuai dengan syariah, diantaranya mudharabah, murabahah, ba'i musawwamah, alqardh, atau akad lainnya. BMT Al-Amanah Ciawi berbentuk Kelompok Swadaya Masyarakat (KSM) atau koperasi yang mengelola dana milik masyarakat dalam bentuk simpanan maupun pembiayaan. Dari sumber itulah pembiayaan BMT

${ }^{3}$ Novita Dewi Masyitoh, 2014, Analisis Normatif Undang-Undang Nomor 1 Tahun 2013 Tentang Lembaga Keuangan Mikro (LKM) atas Status Badan Hukum dan Pengawasan Baitul Mal Wa Tamwil (BMT), Jurnal Economica, Vol.V Edisi 2 Oktober 2014, hlm.18.

4 Warkum Sumitro, Asas-asas Perbankan Islam \& Lembaga-Lembaga Terkait, (Jakarta:CV.Rajawali Pers, 1996), hlm. 114

${ }^{5}$ Nindyo Pramono, Hukum PT Go Public dan Pasar Modal, (Bandung:Andi Publisher, 2006), hlm. 262 
Penerapan Fatwa Dewan Syariah Nasional Tentang Hukum Jaminan

Dalam Akad Pembiayaan Mudharabah

berasal dan dana yang dipercayakan masyarakat kepada BMT dalam bentuk simpanan kemudian disalurkan kembali kepada masyarakat yang membutuhkan dalam bentuk pinjaman. Pola kerja BMT pada akhirnya sama dengan pola kerja perbankan syariah yang menjadi lembaga intermediasi. Menghimpun dana dari masyarakat dan menyalurkan kembali kepada masyarakat. ${ }^{6}$

Pada kenyataanya, produk pembiayaan mudharabah di BMT AIAmanah menetapkan aturan kepada setiap nasabah untuk memberikan jaminan pada transaksi tersebut. Sedangkan pada dasarnya dalam kajian fikih klasik, jaminan dalam akad mudharabah merupakan hal yang tidak diperlukan, mengingat akad mudharabah adalah akad yang didasarkan pada unsur kepercayaan (trust) sehingga eksistensi jaminan dalam akad ini tidak diperlukan. Sejalan dengan perkembangan lembaga-lembaga keuangan syari'ah, ulama semakin tertuntut untuk turut serta dalam memberikan masukan untuk kemajuan lembaga tersebut.

Dalam rangka mengantisipasi tuntutan tersebut, Majelis Ulama Indonesia (MUI) membentuk Dewan Syariah Nasional (DSN) yang dianggap sebagai langkah efisien untuk mengkoordinasikan ulama dalam menanggapi isu-isu yang berhubungan dengan masalah ekonomi atau keuangan. disamping itu, DSN diharapkan dapat berfungsi sebagai pendorong penerapan ajaran Islam dalam kehidupan ekonomi. Oleh karena itu, DSN berperanserta secara proaktif dalam menanggapi perkembangan masyarakat Indonesia dalam bidang ekonomi dan keuangan. $^{7}$

Salah satu produk fatwa DSN-MUI yang berhubungan dengan aplikasi penyaluran dana adalah fatwa DSN-MUI No. 07/DSNMUI/IV/2000 tentang Pembiayaan Mudharabah (Qiradh). Dalam fatwa tersebut terdapat ketentuan pembiayaan bahwa LKS dapat meminta jaminan dari mudharib. Ketentuan tersebut adalah sebagai berikut: "Pada prinsipnya dalam pembiayaan mudharabah tidak ada jaminan, namun agar mudharib tidak melakukan penyimpangan, LKS dapat meminta jaminan dari mudharib atau pihak ketiga, jaminan ini hanya dapat dicairkan apabila mudharib terbukti melakukan pelanggaran terhadap halhal yang telah disepakati bersama dalam akad".

Untuk itulah penulis tertarik meneliti permasalahan tersebut denganmengkaji bagaimana penerapan fatwa DSN tentang jaminan dalam pembiayaan mudharabah di salah satu lembaga keuangan syariah. dan untuk meneliti haltersebut penulis mengambil tempat penelitian di BMT Al-Amanah Ciawi dengan

\footnotetext{
${ }^{6}$ Jurnal Serambi Hukum Vol.11 No. 01 Februari-Juli 2017

7 Jaih Mubarok, Hukum Ekonomi Syariah Akad Mudharabah, (Jakarta: Fokusmedia, 2004),
} hlm.3. 
Penerapan Fatwa Dewan Syariah Nasional Tentang Hukum Jaminan

Dalam Akad Pembiayaan Mudharabah

tema penerapan fatwa dewan syariah nasional tentang hukum jaminan dalam akad pembiayaan mudharabah di BMT Al-Amanah Cabang Ciawi Tasikmalaya.

Dalam kaitanya dengan penelitian ini, agar lebih terpusat kepada substansi permasalahan yang akan dikaji maka penulis akan formulasikan ke dalam bentuk pertanyaan sebagai berikut: bagaimana ketentuan jaminan pada penyaluran pembiayaan mudharabah di lembaga keuangan non bank. Bagaimana jaminan dalam Fatwa DSN-MUI No.07/DSNMUI/IV/2000 tentang pembiayaan mudharabah (Qiradh)? Bagaimana penerapan fatwa DSN tentang jaminan dalam pembiayaan mudharabah di BMT Al-Amanah cabang Ciawi Tasikmalaya.

\section{METODE PENELITIAN}

Metode pada dasarnya berarti cara yang dipergunakan untuk mencapai tujuan. Oleh karena itu metode yang digunakan dalam penelitian ini adalah metode penelitian lapangan (fieldresearch) yaitu, kegiatan penelitian yang dilakukan secara rinci suatu subjek tunggal, satu kumpulan dokumen, atau suatu kejadian tertentu. Jenis pendekatan yang digunakan adalah deskriptif kualitatif.

\section{Jenis Data}

Jenis data yang dikumpulkan dalam penulisan ini adalah data kualitatif, Sebagai jawaban atas pertanyaan penelitian yang diajukan terhadap masalah yang dirumuskan dan pada tujuan yang telah ditetapkan, Jenis data ini digambarkan dengan kata-kata atau kalimat. Jenis data tersebut kemudian diklarifikasikan sesuai pertanyaan yang diajukan, serta menghindari dari jenis data yang tidak relevan dengan pertanyaan tersebut, walaupun dimungkinkan penambahan sebagai pelengkap.

\section{Sumber Data}

Sumber data yang dihimpun dalam penyusunan tulisan ini terdiri dari dua macam sumber, yaitu:

\section{Sumber Data Primer}

Sumber data primer merupakan sumber utama, dalam hal ini adalah datadata yang bersumber dari BMT Al-Amanah Cabang Ciawi Tasikmalaya yang berkaitan dengan praktek penerapan jaminan dalam pembiayaan mudharabah.

\section{Sumber Data Sekunder}

Sumber data sekunder merupakan jenis data yang dapat dijadikan sebagai pendukung data pokok/ merupakan sumber data yang mendukung dan melengkapi 
Penerapan Fatwa Dewan Syariah Nasional Tentang Hukum Jaminan

Dalam Akad Pembiayaan Mudharabah

kekurangan-kekurangan yang ada pada data primer. $^{8}$ Dalam penelitian ini, sumber data sekundernya berupa data-data tentang pelaksaan akad pembiayaan mudharabah, buku-buku, dokumen-dokumen, karya-karya, atau tulisan-tulisan yang berhubungan atau relevan dengan kajian ini.

Teknik Pengumpulan Data

Metode pengumpulan data yang digunakan dalam penelitian ini adalah: Observasi

Observasi yaitu suatu penggalian data dengan cara mengamati, memperhatikan, mendengar dan mencatat terhadap peristiwa, keadaan, atau hal lain yang menjadi sumber data. ${ }^{9}$ Dalam hal ini peneliti langsung ke lapangan yakni di BMT Al-Amanah Cabang Ciawi Tasikmalaya.

\section{Dokumentasi}

Tekhnik pengumpulan data dengan metode dokumentasi adalah cara mencari data atau informasi dari buku-buku, catatan-catatan, transkip, surat kabar, majalah, prasasti, notulen rapat, dan yang lainnya. ${ }^{10}$ Berkaitan dengan penelitian ini, penulis menggunakan buku-buku, dokumen, maupun brosur yang relevan, seperti brosur-brosur mengenai produkproduk di BMT Al-Amanah Cabang Ciawi Tasikmalaya, dokumendokumen lain dari BMT Al-Amanah Ciawi. Serta buku-buku lain yang berkenaan dengan hukum Islam, seperti dokumen fatwa nomor 07/DSNMUI/IV/2000 tentang pembiayaan Mudharabah.

\section{Wawancara}

Pengumpulan data dengan wawancara adalah cara atau tekhnik untuk mendapatkan informasi atau data dari interviewee atau responden dengan wawancara secara langsung face to face, antara interviewer dengan interviewee. ${ }^{11}$ Dapat juga di artikan komunikasi secara langsung antara peneliti dengan responden yang terdiri atas pemudal dan pengelola (mudharib dan shahibul maal) terhadap orang yang menjadi pelaku transaksi. ${ }^{12}$ Dalam penelitian ini, penulis melakukan wawancara dengan pihak dari BMT Al-Amanah Cabang Ciawi Tasikmalaya yakni ketua cabang BMT Al-Amanah Ciawi.

\footnotetext{
${ }^{8}$ Saifuddin Azwar, Metode Penelitian, (Yogyakarta: Pustaka Pelajar Offset, 2001), hlm.91.

${ }^{9}$ Adi Riyanto, , Metodologi Penelitian Social dan Hukum, (Jakarta: Granit, 2004), hlm.70

10 Jusuf Soewadji, Pengantar Motodologi Penelitian, (Jakarta: Mitra Wacana Media, 2012), hlm. 160.

${ }^{11}$ Sugiyono, Metode Penelitian...., hlm.152.

${ }^{12}$ Sukudin dan Mundir, Metode Penelitian: Menimbang dan Mengantar Kesuksesan Anda dalam Dunia Penelitian, (Surabaya: Insan Cendikia, 2005), hlm.218.
} 
Penerapan Fatwa Dewan Syariah Nasional Tentang Hukum Jaminan

Dalam Akad Pembiayaan Mudharabah

Analisis Data

Dalam menganalisa data, peneliti menggunakan teknik analisis data deskriptif dengan lebih banyak bersifat uraian dari hasil wawancara dan dokumentasi. Data yang telah diperoleh akan dianalisis secara kualitatif serta diuraikan dalam bentuk deskriptif. Dimana dalam penelitian ini peneliti menggambarkan tentang gambaran kondisi dan situasi di BMT AIAmanah Cabang Ciawi Tasikmalaya. Sedangkan teknik analisis data deskriptif yaitu suatu analisis yang bersifat mendeskripsikan makna data atau fenomena yang dapat ditangkap oleh peneliti, dengan menunjukkan bukti-buktinya. ${ }^{13}$

Instrumen Penelitian

Instrumen penelitian alat atau fasilitas yang digunakan oleh peneliti dalam mengumpulkan data agar pekerjaanya lebih mudah dan hasilnya lebih baik, dalam arti lebih cermat, lengkap, dan sistematis sehingga lebih mudah diolah. ${ }^{14}$ Berdasarkan teknik pengumpulan data yang digunakan, maka instrument penelitian ini menggunakan panduan wawancara dan panduan dokumentasi.

Pada penelitian ini, penulis melakukan wawancara kepada ketua cabang BMT Al-Amanah Ciawi Tasikmalaya dan kepada staff karyawan yang ada di BMT AlAmanah dan penulis juga meminta dokumen-dokumen yang berkaitan dengan masalah yang akan diteliti. Sehingga mempermudah penulis untuk mendapatkan data yang penulis butuhkan.

HASIL DAN PEMBAHASAN PENELITIAN

Ketentuan Jaminan Penyaluran Pembiayaan Mudharabah di Lembaga Keuangan Non Bank

Perusahaan pembiayaan dalam pemberian pembiayaan mudharabah kepada nasabah, memiliki keyakinan bahwa uang yang telah dicairkan dapat kembali. Oleh sebab itu, pemberian pembiayaan mudharabah wajib didasarkan pada evaluasi secara menyeluruh terhadap kemampuan dan kesanggupan debitur atau nasabah guna melaksanakan kewajibannya sesuai dengan yang diperjanjikan. mengingat pemberian pembiayaan mudharabah dihadapkan pada resiko kegagalan usaha atau kecurangan nasabah di masa yang akan datang, maka untuk mengurangi kerugian apabila nasabah wanprestasi, perusahaan pembiayaan akan mensyaratkan nasabah

\footnotetext{
${ }^{13}$ Muhammad Ali, Strategi Penelitian Pendidikan, Cet.10, (Bandung: Angkasa, 1993), hlm.161.

${ }^{14}$ Ibid., hlm.136.
} 
Penerapan Fatwa Dewan Syariah Nasional Tentang Hukum Jaminan

Dalam Akad Pembiayaan Mudharabah

untuk memberikan jaminan kebendaan sebagai agunan yang didasarkan atas likuidasi nilai agunan.

Penyerahan jaminan dalam akad pembiayaan mudharabah oleh nasabah kepada bank atau lembaga keuangan dapat dikaitkan baik secara langsung maupun tidak langsung dengan peraturan perundangundangan di Indonesia, anatara lain dalam ketentuan UU No.7 Tahun 1992 tentang Perbankan sebagaiamana telah diubah dengan UU No.10 Tahun 1998 tentang Perbankan, dan diperbarui lagi dengan UU No. 21 Tahun 2008 tentang Perbankan Syariah. Ketentuan penyaluran pembiayaan mudharabah baik di perbankan maupun di lembaga keuangan non bank tidak jauh berbeda, salah satu ketentuan dalam penyaluran pembiayaan mudharabah adalah adanya jaminan, seperti yang dituangkan dalam UU Perbankan Indonesia 1992/1998 yang berkaitan dengan jaminan diantaranya: Keharusan penyerahan jaminan oleh nasabah atau debitur, bahwa jaminan merupakan salah satu syarat dalam pemberian pembiayaan di Indonesia.

Penyaluran pembiayaan mudharabah yang dilakukan oleh lembaga keuangan non bank kepada nasabah yakni harus disertai dengan jaminan. Jaminan yang disertakan dapat berupa cash asset (asset lancar) atau fixed asset (asset tetap). Ketentuan barang-barang yang bisa dijadikan jaminan dalam pembiayaan mudharabah dapat dilihat di tabel berikut:

\begin{tabular}{|c|c|c|}
\hline No & Jenis Jaminan & Keterangan \\
\hline 1. & Fixed Asset & $\begin{array}{l}\text { Rumah, jaminannya berupa sertifikat rumah, motor } \\
\text { danmobil jaminannya berupa BPKB minimal usia } 10 \\
\text { tahun } \\
\text { dan fotocopy STNK nya. }\end{array}$ \\
\hline 2. & Cash Asset & $\begin{array}{l}\text { Deposito, giro, logam mulia (emas dan perak), dan } \\
\text { piutang. }\end{array}$ \\
\hline 3. & $\begin{array}{l}\text { Garansi } \\
\text { (personal/company) }\end{array}$ & $\begin{array}{l}\text { 1. Perusahaan yang menggaransikan } \\
\text { jaminannya (company) } \\
\text { 2. Personal guarantee, mudharib yang } \\
\text { merekomendasikan orang lain menjadi } \\
\text { jaminannya. }\end{array}$ \\
\hline
\end{tabular}

1. Untuk menjamin pembayaran kembali secara lunas dan penuh atas seluruh kewajiban nasabah berdasarkan perjanjian maka nasabah harus memberikan jaminan.

2. Ketentuan jaminan di lembaga keuangan non bank adalah sebagai berikut: terdapat kewajiban nasabah berdasarkan perjanjian nasabah wajib memberikan jaminan dalam bentuk, jumlah, nilai serta dengan cara dan persyaratan yang ditentukan oleh perusahaan pembiayaan. 
Penerapan Fatwa Dewan Syariah Nasional Tentang Hukum Jaminan

Dalam Akad Pembiayaan Mudharabah

3. Nasabah dilarang melakukan tindakan-tindakan:

a. Meminjampakaikan, menyewakan, menjaminkan lagi, menjual, mengalihkan atau melepaskan barang yang dijadikan jaminan dengan cara apapun kepada pihak lain tanpa persetujuan tertulis terlebih dahulu dari perusahaan pembiayaan.

b. Membuat barang jaminan menjadi berkurang nilainya sedemikian rupa, sehingga menurut pertimbangan perusahaan pembiayaan menjadi tidak cukup untuk menjamin pembayaran kembali pembiayaan beserta margin, bagi hasil sesuai dengan perjanjian.

4. Selama masih terdapat kewajiban nasabah berdasarkan perjanjian, maka semua pajak-pajak, biaya-biaya yang diwajibkan oleh instansi yang berwenang berkaitan dengan perjanjian ini dan barang jaminan yang diberikan, semua wajib ditanggung dan dibayar oleh nasabah atau penjamin.

Jaminan dalam Fatwa Dewan Syariah Nasional tentang Pembiayaan Mudharabah (Qiradh)

Dituangkan dalam Fatwa Dewan Syariah Nasional No.07/DSNMUI/IV/2000 tentang Pembiayaan Mudharabah (Qiradh) bahwa: Pembiayaan mudharabah adalah pembiayaan yang disalurkan oleh LKS kepada pihak lain untuk suatu usaha yang produktif. Dalam pembiayaan ini, LKS sebagai shahibul maal (pemilik modal) membiayai 100\% kebutuhan suatu proyek (usaha), sedangkan pengusaha (nasabah) bertindak sebagai mudharib atau pengelola usaha.

Berdasarkan fatwa diatas bahwa pembiayaan mudharabah merupakan salah satu produk perbankan syariah dan lembaga keuangan syariah yang memiliki karakteristik berbeda dan memiliki resiko yang lebih besar dibandingkan dengan pembiayaan lainnya. Hal ini menyebabkan Bank Syariah menentukan adanya jaminan bagi nasabah penerima pembiayaan mudharabah. Sebagaimana diatur dalam Undang-Undang Nomor 21 Tahun 2008 tentang Perbankan Syariah. serta fatwa Dewan Syariah.

Nasional Nomor 07/DSN-MUI/IV/2000 dalam Ketentuan Umum pembiayaan mudharabah, pada poin ke tujuh dijelaskan bahwa: "Pada prinsipnya dalam pembiayaan mudharabah tidak ada jaminan, namun agar mudharib tidak melakukan penyimpangan, LKS dapat meminta jaminan dari mudharib atau pihak ketiga. Jaminan ini hanya dapat dicairkan apabila mudharib terbukti melakukan pelanggaran terhadap halhal yang telah disepakati bersama dalam akad.

Meskipun demikian, ketentuan tersebut tidak sejalan dengan asas yang berlaku, yang menetapkan bahwa dalam pembiayaan mudharabah tidak 
Penerapan Fatwa Dewan Syariah Nasional Tentang Hukum Jaminan

Dalam Akad Pembiayaan Mudharabah

dibenarkan adanya jaminan namun bagi lembaga keuangan syariah, jaminan merupakan penerapan prinsip kehatihatian untuk mengantisipasi adanya moral hazard dan assimetric information, dan menjaga dari penyelewengan terhadap perjanjian.

Apabila dicermati, keberadaan jaminan pada pembiayaan mudharabah dapat menjadi perhatian bagi penerima pembiayaan agar dapat mengelola modal yang diterima dengan sebaik-baiknya. Karena salah satu kendala bagi LKS untuk menjalankan pembiayaan tersebut adalah resiko yang sangat tinggi dimana nasabah dapat berlaku curang terhadap LKS. Kondisi masyarakat dewasa ini dan perbedaan cara yang berlaku dalam pembiayaan mudharabah menyebabkan diperlukannya keberadaan jaminan untuk menciptakan kemaslahatan semua pihak yang terlibat selama tidak bertentangan dari aturan pokok.

Jadi, sesuai dengan pemaparan diatas dapat disimpulkan bahwa jaminan dalam akad pembiayaan mudharabah berdasarkan fatwa DSN tersebut diharuskan demi tercapainya tujuan ekonomi Islam, salah satunya kemaslahatan umat. Jaminan dalam fatwa ini dapat mengikat bagi nasabah karena jaminan tersebut akan diambil oleh pemilik modal (shahibul maal) apabila nasabah (mudharib) lalai sehingga dapat menimbulkan kerugian dalam usahanya.

Dalam fatwa diatas juga, yang dimaksud dengan jaminan dalam akad pembiayaan mudharabah itu bahwa jaminan tidak digunakan untuk tujuan mendzolimi nasabah namun untuk mengganti rugi apabila mudharib melakukan cidera janji (wanprestasi) dan hal itu disebabkan hanya untuk memastikan kinerja mudharib sesuai dengan kontrak yang telah disepakati. Mengacu pada fatwa itu, pihak lembaga keuangan syariah membagi kebijakan terhadap penyertaan jaminan dalam pembiayaan mudharabah dipisahkan menjadi tiga tahap:

a. Pre Warranty, menjelaskan mengenai siapa saja yang berhak menjadi pemberi jaminan, megapa perlu ada jaminan dalam pembiayaan mudharabah, dan apa saja yang dapat dijadikan jaminan.

b. In Warranty, menjelaskan bagaimana kebijakan lembaga keuangan jika terjadi fluktuasi ketika harga jaminan bagi jaminan yang berupa asset tetap, apakah jaminan itu dapat dimanfaatkan atau tidak, bagaimana kebijakan apabila nasabah membayar angsuran, dan bagaimana kebijakan jika nasabah yang masih menanggung pembiayaan ternyata meninggal dunia atau wafat.

c. Post Warranty, menjelaskan sikap lembaga keuangan kepada jaminan jika pembiayaan sudah selesai. Apakah ada biaya-biaya yang harus ditanggung oleh nasabah, dan apakah jaminan dikembalikan secara utuh atau dipotong oleh biaya administratif. 
Penerapan Fatwa Dewan Syariah Nasional Tentang Hukum Jaminan

Dalam Akad Pembiayaan Mudharabah

Penerapan Fatwa Dewan Syariah Nasional tentang Jaminan dalam Akad Pembiayaan Mudharabah di BMT Al-Amanah Cabang Ciawi Tasikmalaya

Fatwa merupakan salah satu institusi dalam hukum Islam untuk memberikan jawaban dan solusi terhadap problematika hukum yang dihadapi umat. Kehadiran fatwa menjadi suatu aspek organik dari bangunan ekonomi Islam yang tengah ditata/dikembangkan, sekaligus sebagai alat ukur bagi kemajuan ekonomi syariah

di Indonesia. Fatwa ekonomi syariah yang telah hadir itu secara teknis menyuguhkan model pengembangan bahkan model pembaharuan fiqh muamalah

maliyah (figh ekonomi). Otoritas fatwa tentang ekonomi syariah di Indonesia berada dibawah Dewan Syariah Nasional Majelis Ulama Indonesia (DSN-MUI). Fatwa yang dikeluarkan Komisi Fatwa MUI tersebut menjadi rujukan umum serta mengikat bagi umat Islam di Indonesia, khususnya secara moral. Sedangkan Fatwa DSN menjadi rujukan yang mengikat bagi lembagalembaga keuangan syariah (LKS) demikian pula berlaku bagi masyarakat yang berinteraksi dengan LKS di Indonesia.

Praktek pembiayaan mudharabah yang dilakukan oleh BMT AIAmanah Cabang Ciawi Tasikmalaya ternyata terdapat kewajiban mudharib untuk memberikan jaminan, dan hal itu menyimpang dari teori figh klasik yang mengatakan bahwa dalam perjanjian mudharabah tidak diperlukan dan tidak dibenarkan adanya jaminan. Tidak etis bagi lembaga keuangan syariah meminta

jaminan dalam pembiayaan kerjasama mudharabah mengingat pembiayaan mudharabah ini samasama penyertaan modal. Hal ini didasarkan pada sikap saling membutuhkan dan saling percaya atas pemilik modal (shahibul maal) dan yang akan mengelola modalnya (mudharib) karenanya penerapan jaminan yang dibebankan

pada pengelola modal dinilai tidak mencerminkan nilai mudharabah yang sesungguhnya.

Penerapan fatwa yang dikeluarkan DSN-MUI tentang jaminan dalam pembiayaan mudharabah khususnya di BMT AIAmanah Cabang Ciawi Tasikmalaya memang harus diikuti dan harus diterapkan oleh pihak BMT kepada calon nasabah penyalur pembiayaan mudharabah, mengingat operasional kerja lembaga keuangan syariah tidak lepas dari pengawasan Dewan Pengawas Syariah. Ketentuan tersebut dimungkinkan dapat membentuk pelaku pembiayaan mudharabah dapat menjalankannya dengan benar dan dapat mengurangi atau mencegah terjadinya perilaku curang, seperti perilaku tidak jujur atau aktivitas lain yang dalam teori keuangan disebut dengan moral hazard.

Hubunganya dengan hal ini prinsip-prinsip agama dapat digunakan sebagai pengendali diri, agar seseorang tidak berbuat bohong (hazard), tetapi mereka dapat jujur dalam menyampaikan hasil usaha yang diperoleh. Oleh karena itu, dibentuk 
Penerapan Fatwa Dewan Syariah Nasional Tentang Hukum Jaminan

Dalam Akad Pembiayaan Mudharabah

Dewan Pengawas Syariah di BMT Al-Amanah. Dewan ini, yang melakukan tugas yang berkaitan dengan penegakan prinsip-prinsip syariah dalam pembiayaan keuangan di BMT Al-Amanah. Dengan adanya dewan ini, diharapkan dapat membantu proses pengendalian timbulnya masalah yang disebabkan oleh mudharib.

Selain itu, penerapan fatwa yang diterapkan oleh BMT AIAmanah ini mengacu pada Fatwa Dewan Syariah Nasional No.07/DSN-MUI/IV/2000 poin tujuh. Sebagaimana telah penulis jelaskan pada pembahasan sebelumnya. Hal ini juga sebagaimana dituangkan dalam Peraturan BI Nomor: 7/46/PBI/2005 pasal 6 huruf (o) yang menjelaskan bahwa: Bank dapat meminta jaminan atau agunan untuk mengantisipasi risiko apabila nasabah tidak dapat memenuhi kewajiban sebagimana dimuat dalam akad karena kelalaian dan atau kecurangan. Hal ini sebagai konsekuensi tidak dipenuhinya akad yang telah disepakati. Sementara itu dalam QS.Al-Maidah, 5 : 1 Allah SWT berfirman:

"Hai orang-orang yang beriman! penuhilah akad-akad itu (janji yang telah disepakati)"

Ayat ini merupakan komitmen terhadap perjanjian yang dilakukan. Perjanjian disini tertuju pada perjanjian tertulis dan perjanjian lisan yang dilakukan olehpemilik modal dengan pengelola usaha. Ketika salah satu dari mereka melakukan pelanggaran perjanjian maka bisa dikatakan mereka telah mengingkarinya dan tentu harus ada konsekuensinya. Mengingat tujuan adanya jaminan dalam transaksi mudharabah adalah sebagai pengikat agar pengelola usaha atau mitra usaha kerjasama pada akad mudharabah, beritikad baik; bersungguh-sungguh dalam menjalankan usaha dan amanah sesuai dengan syariat Islam. Ketentuan penerapan ini sesuai dengan kaidah ushul fikih yang berbunyi: "Tidak boleh membahayakan diri sendiri maupun oranglain" (HR.Ibnu Majah).

Tujuan yang lainnya adalah untuk menghindari moral hazard yang dilakukan oleh mitra bisnis mudharabah. Dalam dunia perbankan/non bank adanya jaminan sangat diperlukan sebagai salah satu mitigasi risiko dari mitra bisnis mudharabah mengingat dana yang dikelola adalah dana nasabah yang menuntut adanya likuiditas bank yan g apabila sewaktu-waktu dana tersebut ditarik oleh nasabah. Hal ini sesuai dengan kaidah hukum Islam yang berbunyi: "Kemudharatan itu harus dihilangkan". Maksud dari kaidah ushul figh diatas adalah kewajiban untuk menghindarkan terjadinya kemadharatan atau dalam pengertian lain, kewajiban melakukan usahausaha preventif (pencegahan) agar jangan terjadi suatu 
Penerapan Fatwa Dewan Syariah Nasional Tentang Hukum Jaminan

Dalam Akad Pembiayaan Mudharabah

kemudharatan dengan segala daya upaya yang mungkin dapat diusahakan. Dan kaidah ini juga sesuai dengan maksud maslahah mursalah.

Pada dasarnya dalam analisis pembiayaan di BMT Al-Amanah Cabang Ciawi Tasikmalaya juga menekankan prinsip 5C, yaitu character (karakter), capacity (kemampuan), capital (modal), collateral (jaminan), dan condition (kondisi ekonomi). Prinsip keempat collateral artinya jaminan berarti bahwa pihak BMT dalam melakukan pendekatan analisis pembiayaan selalu memperhatikan kuantitas dan kualitas jaminan yang dimiliki oleh peminjam. DSN menyebutkan bahwa jaminan dapat dicairkan jika terjadi penyimpangan.

Secara umum, penyimpangan timbul karena adanya bahaya moral (moral hazard). Bahaya moral terjadi ketika masalah moral dan etika dalam berbisnis tidak diindahkan, salah satunya pembukuan laporan keuangan yang direkayasa oleh calon mudharib. Berdasarkan faktor itu pulalah Dewan Syariah Nasional mengeluarkan fatwa No. 07/DSN-MUI/IV/2000 poin tujuh mengenai jaminan dalam pembiayaan mudharabah (Qiradh).

Selain itu, untuk mengurangi kemungkinan terjadinya moral hazard, maka BMT Al-Amanah Cabang Ciawi Tasikmalaya menerapkan sejumlah batasa-batasan tertentu ketika menyalurkan pembiayaan kepada mudharib, yaitu:

- Menerapkan batasan agar dalam pembiayaan mudharabah harus adanya jaminan, dan nilai barang yang dijadikan jaminan harus lebih besar daripada dana yang diminta oleh mudharib.

- Menerapkan syarat agar mudharib melakukan bisnis yang risiko operasinya lebih rendah.

- Menerapkan syarat agar mudhraib melakukan bisnis dengan arus kas yang transparan kepada pihak BMT Al-Amanah.

Batasan atau syarat tersebut diatas merupakan bagian dari proses monitoring

dan supervis BMT AlAmanah Cabang Ciawi Tasikmalaya atas pembiayaan mudharabah yang disalurkan. Bahwa dengan meningkatkan pemantauan dan pengawasan, dapat meminimalisasi terjadinya penyimpangan yang dilakukan oleh mudharib.

Berdasarkan analisis diatas, maka dapatlah penulis tarik benang erah, dimana dalam hal penerapan fatwa DSN tentang jaminan dalam akad pembiayaan mudharabah ini tentunya tidak terlepas dari kaidah ushul fiqh yang satu ini, yang sering digunakan: "Hukum asal bermuamalah itu adalah boleh selama tidak ada dalil yang mengharamkanya." Maksud dari kaidah ini adalah bahwa dalam setiap praktek muamalah dan transaksi pada dasarnya boleh, seperti jual beli, sewa menyewa, gadai, kerjasama (mudharabah atau musyarakah), perwakilan, dan lain- lain, kecuali yang tegas-tegas diharamkan seperti mengakibatkan kemudharatan 
Penerapan Fatwa Dewan Syariah Nasional Tentang Hukum Jaminan

Dalam Akad Pembiayaan Mudharabah

judi dan riba. Kemudiaan kaitanya kaidah ini dengan penerapan fatwa tentang jaminan dalam akad pembiayaan mudharabah yang dilakukan oleh BMT Al-Amanah Cabang Ciawi Tasikmalaya ini jelas diperbolehkan bahkan demi tercapainya kemaslahatan umat.

\section{SIMPULAN}

Adapun kesimpulan hasil penelitian penulis dapat dipaparkan dalam beberapa poin: ketentuan jaminan pada penyaluran pembiayaan mudharabah di lembaga keuangan non bank didasarkan pada besarnya modal dalam pembiayaan mudharabah yang diajukan dan hasil evaluasi secara menyeluruh terhadap kemampuan dan kesanggupan nasabah (mudharib) dalam melaksanakan kewajibannya sesuai dengan perjanjian yang telah dibuat. Ketentuan jaminan dalam penyaluran pembiayaan mudharabah dapat berupa cash asset (aset lancar) fixed asset (aset tetap). Pada intinya ketentuan jaminan dalam penyaluran pembiayaan mudharabah dapat disimpulkan bahwa setiap nasabah yang mengajukan pembiayaan mudharabah maka diwajibkan untuk meyerahkan jaminan kepada pihak penyalur dana, jaminan harus sesuai dengan apa yang diminta oleh lembaga penyalur dana dan nasabah tidak boleh melakukan kecurangan terhadap apa yang dijadikan jaminannya itu.

Hasil penelitian tentang jaminan dalam fatwa dewan syariah nasional tentang pembiayaan mudharabah (qiradh) bahwa jaminan yang diminta oleh pihak lembaga keuangan syariah (LKS) kepada nasabah yang mengajukan pembiayaan mudharabah tidak digunakan untuk tujuan mendzolimi nasabah, namun hanya untuk memastikan kerja nasabah selaku mudharib untuk tidak melakukan hal yang menyimpang dengan perjanjian tersebut. Karena jaminan itu sifatnya mengikat maka apabila nasabah melakukan cidera janji (wanprestasi), jaminan itu dapat dijadikan sebagai cara untuk mengganti rugi atas kerugian yang ditanggung oleh LKS selaku pemilik dana (shahibul maal) dengan kata lain konsekuensi dari apa yang telah dilakukan oleh mudharib. Mengacu pada fatwa tersebut, pihak LKS membagi kebijakannya terhadap penyertaan jaminan dalam pembiayaan mudharabah menjadi 3 tahap yakni Pre Warranty, In Warranty, dan Post Warranty.

Hasil penelitian tentang penerapan fatwa dewan syariah nasional tentang jaminan dalam akad pembiayaan mudharabah di BMT Al-Amanah Cabang Ciawi Tasikmalaya adalah bahwa jaminan dalam akad pembiayaan mudharabah diwajibkan kepada setiap nasabah yang mengajukan pembiayaan mudharabah mengingat dalam hal ini juga berdasarkan kondisi masyarakat yang sering melakukan penyimpangan sosial (moral hazard) atau sering disebut dengan cidera janji (wanprestasi). 
Penerapan Fatwa Dewan Syariah Nasional Tentang Hukum Jaminan

Dalam Akad Pembiayaan Mudharabah

DAFTAR PUSTAKA

Ali, Zainuddin, 2008. Hukum Islam Pengantar IImu Hukum Islam di Indonesia. Jakarta: Sinar Grafika.

Antonio, Syafi'i. 2001. Bank Syariah; Dari Teori ke Praktik. Cet.I, Jakarta: Gema Insani Press.

Arikunto, Suharsimi. 1993. Prosedur Penelitian: Suatu Pendekatan Praktek. Jakarta: PT. Rineka Cipta.

Ascarya. 2007. Akad \& Produk Bank Syariah, Edisi. I, Jakarta: PT. Raja Grafindo Persada.

Ath-Thayar, Muhammad Abdullah, dkk,. 2009. Ensiklopedia Fiqih Muamalah dalam Pandangan 4 Mazhab, penerjemah Miftahul Khairi, cet. I. Yogyakarta: Makatabah Al-Haniy.

Badrulzaman, Mariam Darus. 1998. Kerangka Hukum Jaminan Indonesia Dalam hukum Jaminan Indonesia Seri Dasar Hukum Ekonomi 4. Bandung: CitraAditya Bakti.

Basyir, Ahmad Azhar. 2000. Asas-Asas Hukum Muamalat, cet. I. Yogyakarta: UII Press.

Chapra, Umar. 2000. Sistem Moneter Islam alih bahasa Ikhwan Abidin Busyri. cet I. Jakarta: Gema Insani Press.

Departemen Agama. 1989. Al-Qur'an dan Terjemahannya. Bandung: Lubuk Agung. Dewan Syari'ah Nasional MUI dan Bank Indonesia, 2006. Himpunan Fatwa Dewan Syari'ah Nasional MUI. cet. ke-3. Jakarta: CV. Gaung Persada.

Djazuli, A. 2006. Kaidah-Kaidah Fikih, Cet. I. Jakarta: Kencana Prenada.

Fatwa Dewan Syari'ah Nasional Majelis Ulama Indonesia Nomor: 07/DSNMUI/IV/2000 tentang Pembiayaan Muārabah (Qiradh).

G. Kazarian, Elias. 1999. Islamic Versus Traditional Banking, Financial Innovation in Egypt. Boulder (et.al) : Westview Press.

Hoey Tiong, Oey. 1985. Fiducia Sebagai Jaminan Unsur-unsur Perikatan. Jakarta: Ghalia Indonesia.

Hasan, Djuhaendah. 1998. Perjanijan Jaminan Dalam Perjanjian Kredit. Jakarta: Proyek Elips dan Fakultas Hukum Universitas Indonesia.

Karim, Adiwarman. 2010. Bank Islam Analisis Fikih dan Keuangan, cet. ke-7. Jakarta: PT. Raja Grafindo.

Karim, Helmi. Fiqh Muamalah. 1993. Jakarta: PT. Raja Grafindo Persada.

Mas'ud, Khalid. 2003. Filsafat Hukum Islam. cet. I. Bandung: Pustaka Pelajar.

Mas'adi, Ghufron A. 2002. Fiqh Muamalah Konstektual. Jakarta: Raja Grafindo Persada, Cet. Pertama. 
Penerapan Fatwa Dewan Syariah Nasional Tentang Hukum Jaminan

Dalam Akad Pembiayaan Mudharabah

Muhammad. 2005. Manajemen Pembiayaan Bank Syariah. Yogyakarta: UPP AMP YMKN.

Mustofa dan Wahid, Abdul. 2001. Hukum Islam Kontemporer. Jakarta: Sinar Grafindo.

Muhtar, Kamal. 2000. Maslahat Sebagai Dalil Dalam Penetapan Hukum Islam Masalah Kontemporer. Yogyakarta: IAIN Sunan Kalijaga,

Moleong, Lexy J. 2002. Metodologi Penelitian Kualitatif, Bandung: PT Remaja Rosdakarya.

Ridwan, Muhammad. 2004. Manajemen Baitul Maal wa Tamwil (BMT). Yogyakarta: UII Press.

Rivai, Veithzal dan Arifin, Arviyan. Islamic Banking: Sebuah Teori, Konsep, dan Aplikasi, Cet. I, Jakarta: Bumi Aksara, 2010.

Rusyd, Ibnu. 1995. Bidayatul Mujtahid, Terj. Imam Ghazali Said dan A. Zaidun, Jilid 4 Cet.I. Jakarta: Pustaka Amani.

Sabiq, As-Sayyid, 2008. Fiqih Sunnah, penerjemah Nor Hasanuddin, dkk, Cet. III. Jakarta : Pena Pundi Aksara.

Sholihin, Ahmad Ifham. 2010. Buku Pintar Ekonomi Syariah. Jakarta: PT. Gramedia Pustaka Utama.

SM, Imi Makhalul. 2002. Teori \& Praktek Lembaga Mikro Keuangan Syariah. Yogyakarta: UII Press.

Sula, Muhammad Syakir. 2004. Asuransi Syariah (Life and General): Konsep dan Sistem Operasional. Jakarta: Gema Insani.

Sugiyono. 2017. Metode Penelitian Kualitatif, Kuantitatif, dan R\&D. Bandung: Alfabeta.

Sudarsono, Heri. 2004. Bank dan Lembaga Keuangan Syari'ah, Diskripsi dan Ilustrasi. Yogyakarta: Ekonesik.

Sumiyanto, Ahmad. 2005. Problem dan Solusi Transaksi Mudharabah di Lembaga Keuangan Syari'ah Mikro Baitul Maal wat Tamwil. Yogyakarta: Megistra Insania Press.

Sumitro, Warkum. 2004. Asas-Asas Perbankan Islam dan Lembaga Terkait Bamui \& Takaful Di Indonesia. Jakarta: PT Raja Grafindo Persada.

Suryabrata, Sumadi. Metodologi Penelitian, 1998. Cet. Ke- 11. Jakarta: PT Raja Grafindo.

Syafe'i, Rachmat. 1999. Ilmu Ushul Fiqih. Bandung: PustakaSetia.

Undang-Undang No. 10 Tahun 1998 Tentang Perbankan UndangUndang NO. 21 Tahun 2008 Tentang Perbankan Syariah Peraturan Bank Indonesia No. 11/10/2009 Tentang Unit Usaha Syariah

Wangsawidjaja.2012. Pembiayaan Bank Syariah. Jakarta: Gramedia Pustaka Utama. 
Penerapan Fatwa Dewan Syariah Nasional Tentang Hukum Jaminan

Dalam Akad Pembiayaan Mudharabah

Zahrah, Abu Muhammad. 2008. Ushul Fiqih, alih bahasa Saefullah Ma'shum dkk, cet. XI. Jakarta: Pustaka Firdaus.

Zuhaili ,Wahbah. 1986. Alfighul Islamy Wa Adillatuh, Juz 4. Damaskus: Darul Maktabah.

Zuhaili, Wahbah. 2010. Fiqh Imam Syafi'i, penerjemah Muhammad Afifi dan Abdul Hafiz. Jilid 2, cet. I Jakarta: Niaga Swadaya.

https://www.academia.edu/9844341/Kaidah-Adh-dharuriyah. (diakses pada 28

Januari 2018) https://dsnmui.or.id (diakses pada tanggal 28 Juli 2018)

https://www.google.co.id/amp/s/www.syariahbank.com/mengenal-dewan-

yariahnasional/amp/ (diakses pada 28 Juli 2018)

http://maxzhum.wordpress.com/200 9/04/22/fungsi-dewansyariah-nasional-dandewanpengawas-syariah/ (diakses pada 26 Juli 2018) 